4 Evidence of peptide oxidation from major myofibrillar proteins in dry-

5

6

7

8

9

\title{
cured ham
}

6

Marta Gallego, Leticia Mora, M. Concepción Aristoy, and Fidel Toldrá*

8

(1)

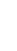

4

5

* Corresponding author: Tel: +34963900022 ext.2112; fax: +34963636301.

E-mail address: ftoldra@iata.csic.es 


\section{Abstract}

32 In this study, a peptidomic approach has been used in the identification of naturally

33 generated peptides during dry-curing process showing methionine (Met) oxidation in

34 their sequence. A total of 656 peptides derived from major myofibrillar proteins in

35 Protected Designation of Origin (PDO) Teruel dry-cured ham have been identified by

36 nanoliquid chromatography coupled to tandem mass spectrometry (nLC-MS/MS),

37 including 120 peptides showing methionine oxidation. The percentage of oxidised

38 peptides in the studied proteins ranged from 6 to $35 \%$, being peptides derived from

39 nebulin, titin, myosin heavy chains, and troponin I proteins, those showing the highest

40 number of oxidised methionine. The identification of the peptide sequence

41 incorporating the oxidised amino acid provides valuable information of neighbouring

42 amino acids, degree of hydrolysis of the sample, and characteristics of the peptide,

43 which might be very useful for a future better understanding of the oxidation

44 mechanisms occurring in dry-curing processing.

45

46

47

48

49

50

51

52

Keywords: Methionine, oxidation, peptides, dry-cured ham, proteomics, mass spectrometry. 


\section{Introduction}

54 Teruel dry-cured ham was the first Spanish meat product with accepted Protected Designation of Origin (PDO). This denomination was created to control and guarantee the traditional manufacture that yields in high quality dry-cured ham with typical organoleptic and nutritional characteristics. The final product is the result of numerous and complex biochemical reactions which take place along the fourteen months of Teruel dry-cured ham processing. Proteolysis is the most important reaction that generates large amounts of peptides and free amino acids from the degradation of myofibrillar and sarcoplasmic proteins by the action of endogenous muscle peptidases (Toldrá, Rico, \& Flores, 1993; Aristoy, \& Toldrá, 1995; Toldrá, \& Flores, 1998; Lametsch, Karlsson, Rosenvold, Andersen, Roepstorff, \& Bendixen, 2003).

Oxidation of lipids and proteins is the main cause for quality deterioration during processing and storage of meat products, causing changes in nutritional value and sensory traits (Ladikos, \& Lougovois, 1990; Lund, Heinonen, Baron, \& Estévez, 2011). However, lipid oxidation is also essential in the maturation process and the desirable flavour of dry-cured hams, being this process extensively studied (Antequera, et al., 1992; Toldrá, \& Flores, 1998; Ruiz, Ventanas, Cava, Andrés, \& García, 1999; Gandemer, 2002). On the other hand, protein oxidation has been less studied in drycured hams, even though certain increase from the salting stage and tending to stabilise towards the ham maturation period have been reported (Armenteros, Heinonen, Ollilainen, Toldrá, \& Estévez, 2009; Estévez, 2011; Wang, Xu, Zhang, Li, Lin, \& Ma, 2011; Koutina, Jongberg, \& Skibsted, 2012). In fact, the oxidation of muscle proteins comprises colour, flavour and texture deterioration as well as the loss of essential amino acids, and changes in conformation and functionality of proteins due to oxidative 
derivatives, (ii) cleavage of peptide bonds, and (iii) modification of amino acid side chains (Estévez, Ventanas, \& Cava, 2005; Estévez, 2011; Lund, et al., 2011; Zhang, Xiao, \& Ahn, 2013).

81 During the last decades, most of the studies about protein oxidation have been focused 82 on the role played by oxidised proteins in different human diseases whereas the 83 mechanisms of protein oxidation in food systems are largely unknown (Elias, Kellerby, $84 \&$ Decker, 2008). The oxidation of essential amino acids has been a concern because of its effect on meat quality but also on the nutritive value due to the decreased availability of essential amino acids and poorer digestibility of oxidized proteins (Lund, et al., 2011).

87 However, although the oxidation of proteins has been described, no information about 88 the identification of oxidised peptides generated during dry-cured ham processing has 89 been reported to date.

90 Methionine is one of the most susceptible amino acids to oxidation by almost all forms

91 of reactive oxygen species because of its reactive sulfur atom, leading to modifications 92 in structure of proteins and loss of enzyme activity (Zhang, et al., 2013). The first and 93 the main oxidation product formed is methionine sulfoxide, which can be further 94 oxidised, although a lesser amount, to methionine sulfone (Vogt, 1995; Shacter, 2000). 95 However, the oxidation can be reversible due to the action of methionine sulfoxide 96 reductases, which reduce methionine sulfoxides to methionine residues. Moreover, this 97 cyclic oxidation-reduction process could act in antioxidant mechanisms and in 98 regulation of cellular processes (Levine, Mosoni, Berlett, \& Stadtman, 1996; 99 Ghesquière, \& Gevaert, 2014; Kim, Weiss, \& Levine, 2014).

100 In the present work, a peptidomic strategy has been used to identify and sequence those 101 naturally generated peptides showing methionine oxidation in PDO Teruel dry-cured 
102 ham, focusing on those peptides derived from the degradation of the major myofibrillar

103 proteins along the dry-curing process.

104

\section{2. Materials and methods}

\section{$106 \quad 2.1$ Materials}

107 Dry-cured hams manufactured according to the specifications of PDO Teruel (Spain)

108 were used in this study. Hams were obtained from white-breed pigs (maternal line

109 Landrace $\mathrm{x}$ Large White, and paternal line Duroc) and prepared according to the

110 traditional process until a total time of processing of fourteen months.

\section{$111 \quad 2.2$ Extraction of peptides}

112 A total of $100 \mathrm{~g}$ of Biceps femoris muscle from the dry-cured hams were minced and

113 homogenised with $500 \mathrm{~mL}$ of $0.01 \mathrm{~N} \mathrm{HCl}$ for $5 \mathrm{~min}$ using an Ultra-Turrax ${ }^{\circledR} \mathrm{T}-25$

114 (IKA ${ }^{\circledR}$-Werke, Germany). The homogenate was kept at $4{ }^{\circ} \mathrm{C}$ overnight for decanting,

115 and the supernatant was filtered to retain the large pieces, firstly through a plastic mesh,

116 and secondly through a qualitative filter paper (Whatman ${ }^{\mathrm{TM}}$, UK). Afterwards, the

117 sample was freeze-dried and desalted by solid phase extraction using an Oasis ${ }^{\circledR}$ HLB

118 cartridge (35cc, Waters, Ireland) in which peptides were retained and then eluted with

119 methanol:water $(95: 5, \mathrm{v} / \mathrm{v})$. Finally, the sample was lyophilised for the following

120 analysis by tandem mass spectrometry.

\section{$121 \quad 2.3$ Peptide identification by nESI-LC-MS/MS}

122 The identification of the peptides was performed by nanoliquid chromatography-tandem

123 mass spectrometry using an Eksigent Nano-LC Ultra 1D Plus system (Eksigent of AB

124 Sciex, CA, USA) and a quadrupole/time-of-flight (Q-ToF) TripleTOF® 5600+ system

125 (AB Sciex Instruments, MA, USA) with a nanoelectrospray ionisation source (ESI). 
126 Desalted and lyophilised samples were resuspended to $10 \mathrm{mg} / \mathrm{mL}$ with $0.1 \%$ of TFA

127 and centrifuged in cold at $200 \mathrm{~g}$ for $3 \mathrm{~min}$. Then, $15 \mu \mathrm{L}$ of the sample were cleaned and

128 concentrated using Zip-Tip C18 with standard bed format (Millipore Corporation,

129 Bedford, MA) according to the manufacturer recommendations. Peptides eluted from

130 Zip-Tip were dried and then resuspended in $20 \mu \mathrm{L}$ of $0.1 \%$ of TFA.

131 Five microliters of the sample were injected into the nESI-LC-MS/MS system. Sample

132 was preconcentrated on an Eksigent C18 trap column $(3 \mu, 350 \mu \mathrm{m} \times 0.5 \mathrm{~mm}$; Eksigent of

$133 \mathrm{AB}$ Sciex, CA, USA), at a flow rate of $3 \mu \mathrm{L} / \mathrm{min}$ for $5 \mathrm{~min}$ and using $0.1 \% \mathrm{v} / \mathrm{v}$ TFA as

134 mobile phase. Then, the trap column was automatically switched in-line onto a nano-

135 HPLC capillary column $(3 \mu \mathrm{m}, 75 \mu \mathrm{m}$ x $12.3 \mathrm{~cm}, \mathrm{C} 18$; Nikkyo Technos Co, Ltd. Japan).

136 Mobile phases consisted of solvent A, containing $0.1 \% \mathrm{v} / \mathrm{v}$ formic acid in water, and

137 solvent $\mathrm{B}$, containing $0.1 \% \mathrm{v} / \mathrm{v}$ formic acid in $100 \%$ acetonitrile. The LC conditions

138 were a linear gradient from $5 \%$ to $35 \%$ of solvent B over $90 \mathrm{~min}$, and $10 \mathrm{~min}$ from $35 \%$

139 to $65 \%$ of solvent $\mathrm{B}$, at a flow rate of $0.30 \mu \mathrm{L} / \mathrm{min}$ and temperature of $30^{\circ} \mathrm{C}$.

140 The column outlet was directly coupled to a nano-electrospray ionisation system (nano-

141 ESI). The Q/ToF was operated in positive polarity and information-dependent

142 acquisition mode, in which a $0.25-\mathrm{s}$ ToF MS scan from $\mathrm{m} / \mathrm{z}$ of 100 to 1250 was

143 performed, followed by 0.05 -s product ion scans from $\mathrm{m} / z$ of 100 to 1500 on the 50

144 most intense 1 - 5 charged ions.

\section{$145 \quad 2.4$ Data analysis}

146 Mascot Distiller v2.5.1. software (Matrix Science, Inc., Boston, MA, USA;

147 http://www.matrixscience.com) has been used for automated spectral processing, peak

148 list generation, and database search. The identification of peptides has been performed

149 using UniProt database, the taxonomy parameter was designated as Mammalia, and

150 oxidation of methionine $(\mathrm{M})$ was selected as variable modification. Other amino acid 
151 oxidations such as cysteine (C), histidine-tryptophan (HW), and proline (P) have been

152 also tested with non-significant results. Generated MS/MS spectra were searched using 153 a significant threshold of $p<0.1$, a FDR of $1.5 \%$, and a peptide tolerance on the mass 154 measurements of 0.3 Da in MS mode and MS/MS ions.

\section{3. Results and discussion}

157 Teruel dry-cured ham peptide extracts have been analysed by nESI-LC-MS/MS to 158 identify those peptides showing oxidation in their methionine residues. As a result of 159 the intense proteolysis which takes place along the dry-curing process of ham, 160 approximately 62,000 peptides have been identified, including more than 17,700 which 161 contain oxidations of methionine. In this study, only peptides derived from the 162 degradation of major myofibrillar proteins were selected, comprising 120 peptides with 163 methionine oxidation from a total of 656 peptides resulting from the degradation of $\alpha$ 164 actin (ACTS), nebulin (NEBU), titin (TITIN), troponin I fast skeletal muscle (TNNI2), 165 two types of myosin light chain proteins (myosin regulatory light chain 2 (MLRS) and 166 myosin light chain (MYL1)), and two types of myosin heavy chain proteins (myosin-1 167 (MYH1) and myosin-7 (MYH7)).

168 Tables 1 and 2 show the sequences of the oxidised peptides, the protein of origin as well 169 as the species in which it has been described, the observed and calculated masses 170 together with the charge states, amino acid residues preceding and following the 171 sequence, and the number of methionine oxidations detected in the peptide. Some of the 172 identified peptides have been detected both with and without methionine oxidations (see 173 those marked with an asterisk in Tables 1 and 2). This difference results on an earlier 174 elution of the oxidised peptides from reversed-phase columns and a molecular mass 175 increase of 16 Da for the respective non-oxidised peptides (Liu, Ponniah, Neill, Patel, \& 
176 Andrien, 2013). Three, two, four, and eight peptides derived from ACTS, MLRS,

177 MYH1, and MYL1 proteins, respectively, were present in both oxidised and non-

178 oxidised forms. Differences on both type of spectrums are described in Figure 1, where

179 MS/MS spectrums of peptide DKEGNGTVMGAELR with and without methionine

180 oxidation from MYL1 protein are shown.

181 Cysteine and methionine are the most susceptible amino acids to oxidative changes

182 (Zhang, et al., 2013). Nevertheless, Cys, but also His-Trp, and Pro oxidations were also

183 included in the search with the result that only Met oxidations were detected.

184 Table 3 lists the number of oxidised peptides compared to the total number of peptides

185 identified for each protein as well as the total percentage of methionine amino acid on

186 the studied sequences. Although theoretically, a high presence of Met residues on a

187 sequence could indicate a higher predisposition for oxidation, not all methionine

188 residues in a protein are susceptible in the same way because it depends on their

189 location within the protein structure and their accessibility to oxidants. In fact, the

190 highest percentages of Met are present in ACTS, TNNI2, and both myosin light chain

191 proteins $(4.5,5.5,4.1$, and $3.4 \%$, respectively), but corresponds to the lowest

192 percentages of identified oxidised peptides (11.6, 22.2, 5.9, and 7.4\%, respectively).

193 The fact that these are the smallest of the studied proteins and those showing the highest

194 sequence coverage when identifying the sequence of the generated peptides, could be

195 due to heavier proteins such as TITIN, NEBU, or MYH also show more complex

196 structures that difficult the hydrolysis, showing lower percentages of sequence coverage.

197 TITIN, NEBU, and MYH showed the highest percentage of oxidation, comprising

198 between 35 and $17 \%$ of the total number of peptides identified from their sequences.

199 The neighbouring amino acid residues also determine methionine oxidation, being those

200 surrounded by Ala, Thr, Ser, and acidic amino acids such as Asp and Glu more 
susceptible to oxidation than Met located close to basic amino acids (Levine, et al.,

202 1996; Ghesquière, \& Gevaert, 2014). In this study, a total of 61 of the 120 oxidised 203 peptides identified in dry-cured ham extract show Asp, Glu, Ala, Thr and Ser residues 204 next to the oxidised Met. However, only 31 of the identified peptides showing oxidation 205 had any of the basic amino acids Arg, Lys, and His next to the oxidised Met.

206 Methionine oxidation can be caused by different factors, being influenced from the 207 oxidative stress suffered by the animal from the slaughtering up to the meat industry 208 processing and sample preparation and analysis. In fact, technological operations such 209 as pre-freezing, pre-mincing or packaging have been described to have a great impact 210 on the oxidation of muscle proteins (Utrera \& Estévez, 2013; Utrera, Parra \& Estévez, 211 2014). On the other hand, methionine amino acids have also been described to be 212 spontaneously oxidised during sample preparation, chromatography separation and 213 ionisation of MS analysis (Liu, et al., 2013; Drazic, \& Winter, 2014), although it has

214 been established that these factors, when occur, do not represent more than $2 \%$ of total 215 amount of Met oxidations.

216 Recently, it has been described that oxidative protein modifications in dry-cured 217 products are accelerated during first steps of processing but stabilised towards the final 218 stages of maturation (Koutina, et al., 2012). Same authors also showed that oxidation 219 may change the susceptibility of proteins to the proteolytic enzymes in Parma ham, 220 influencing the proteolysis reactions (Koutina, et al., 2012). Proteolysis, protein 221 oxidation and peptidases activity have also been studied in Xuanwei ham, concluding 222 that although oxidation occurs during salting stage, it is deccelerated due to the low temperatures employed (Wang, et al., 2011). Finally, Gallego, Mora, Fraser, Aristoy, and Toldrá (2014) reported the identification by LC-MS/MS of some peptides derived 
225 from LIM domain-binding protein showing methionine oxidation in dry-cured hams at

226 different times of ripening, identifying most of them at the end of the processing.

227

\section{4. Conclusions}

229 This study evidences the importance of methionine oxidation in dry-cured ham 230 processing by identifying a total of 120 sequences of peptides including a minimum of 231 one oxidised Met in their sequence. The described peptidomic approach gives a new 232 point of view in the detection and identification of those peptides responsible for the 233 oxidation and provides valuable information of neighbouring amino acids, degree of 234 hydrolysis of the sample, proteins of origin affected, and characteristics of the peptide, 235 which might be very useful to better understand and characterise the complex oxidation 236 mechanisms occurring in dry-curing processing.

\section{Acknowledgements}

239 Grant AGL2013-47169-R from MINECO and FEDER funds and FPI Scholarship BES-

240 2011-046096 from MINECO (Spain) to M.G. are fully acknowledged. JAEDOC-CSIC

241 postdoctoral contract to L.M. is also acknowledged. The proteomic analysis was carried out in the SCSIE_University of Valencia Proteomics Unit, a member of ISCIII ProteoRed Proteomics Platform. 


\section{References}

251 Antequera, T., López-Bote, C.J., Córdoba, J.J., García, C., Asensio, M.A., Ventanas, J., García-Regueiro, J.A., \& Díaz, I. (1992). Lipid oxidative changes in the processing of Iberian pig hams. Food Chemistry, 45 (2), 105-110.

Aristoy, M.C., \& Toldrá, F. (1995). Isolation of flavor peptides from raw pork meat and dry-cured ham. In G. Charalambous (Ed.), Food flavors: Generation, analysis and processes influence (pp. 1323-1344). Amsterdam: Elsevier Science.

Armenteros, M., Heinonen, M., Ollilainen, V., Toldrá, T., \& Estévez, M. (2009). Analysis of protein carbonyls in meat products by using the DNPH-method, fluorescence spectroscopy and liquid chromatography-electrospray ionisation-mass spectrometry (LC-ESI-MS). Meat Science, 83, 104-112.

Drazic, A, \& Winter, J. (2014). The physiological role of reversible methionine oxidation. Biochimica et Biophysica Acta - Proteins and Proteomics, 1844 (8), $1367-1382$.

Elias, R. J., Kellerby, S. S., \& Decker, E. A. (2008). Antioxidant activity of proteins and peptides. Critical Reviews in Food Science and Nutrition, 48, 430-441. deterioration. Journal of Food Science, 70, C427-C432.

269 Estévez, M. (2011). Protein carbonyls in meat systems: A review. Meat Science, 89 (3), 259-279.

Gallego, M., Mora, L., Fraser, P.D., Aristoy, M.A, \& Toldrá, F. (2014). Degradation of LIM domain-binding protein three during processing of Spanish dry-cured ham. Food Chemistry 149, 121-128. 
274 Gandemer, G. (2002). Lipids in muscles and adipose tissues, changes during processing and sensory properties of meat products. Meat Science, 62 (3), 309-321.

276 Ghesquière, B., \& Gevaert, K. (2014). Proteomics methods to study methionine oxidation. Mass Spectrometry Reviews, 33 (2), 147-156.

Kim, G., Weiss, S.J., \& Levine, R.L. (2014). Methionine oxidation and reduction in proteins. Biochimica et Biophysica Acta - General Subjects, 1840 (2), 901-905.

Koutina, G., Jongberg, S., \& Skibsted, L.H. (2012). Protein and lipid oxidation in Parma ham during production. Journal of Agricultural and Food Chemistry, 60 (38), 9737-9745.

Ladikos, D., \& Lougovois, V. (1990). Lipid oxidation in muscle foods - a review. Food Chemistry, 35 (4), 295-314.

Lametsch, R., Karlsson, A., Rosenvold, K., Andersen, H. J., Roepstorff, P., \& Bendixen, E. (2003). Postmortem proteome changes of porcine muscle related to tenderness. Journal of Agricultural and Food Chemistry, 51 (24), 6992-6997.

Levine, R.L., Mosoni, L., Berlett, B.S., \& Stadtman, E.R. (1996). Methionine residues as endogenous antioxidants in proteins. Proceedings of the National Academy of Sciences of the United States of America, 93 (26), 15036-15040.

Liu, H., Ponniah, G., Neill, A., Patel, R., \& Andrien, B. (2013). Accurate determination of protein methionine oxidation by stable isotope labeling and LC-MS analysis. Analytical Chemistry, 85 (24), 11705-11709.

Lund, M.N., Heinonen, M., Baron, C.P., \& Estévez, M. (2011). Protein oxidation in muscle foods: A review. Molecular Nutrition and Food Research, 55 (1), 8395. 
Ruiz, J., Ventanas, J., Cava, R., Andrés, A., \& García, C. (1999). Volatile compounds of dry-cured Iberian ham as affected by the length of the curing process. Meat Science, 52 (1), 19-27.

Shacter, E. (2000). Quantification and significance of protein oxidation in biological samples. Drug Metabolism Reviews, 32 (3-4), 307-326.

Toldrá, F., Rico E., \& Flores, J. (1993). Cathepsin B, D, H and L activity in the processing of dry-cured ham. Journal of the Science of Food and Agriculture, $62(2), 157-161$.

Toldrá, F., \& Flores, M. (1998). The role of muscle proteases and lipases in flavor development during the processing of dry-cured ham. Critical Reviews in Food Science and Nutrition, 38 (4), 331-352.

Utrera, M., \& Estévez, M. (2013). Oxidative damage to poultry, pork, and beef during frozen storage through the analysis of novel protein oxidation markers. Journal of Agricultural and Food Chemistry, 61 (33), 7987-7993.

Utrera, M., Parra, V., \& Estévez, M. (2014). Protein oxidation during frozen storage and subsequent processing of different beef muscles. Meat Science, 96 (1), 812-820.

Vogt, W. (1995) Oxidation of methionyl residues in proteins: Tools, targets, and reversal. Free Radical Biology and Medicine, 18 (1), 93-105.

Wang, Z., Xu, Y., Zhang, J., Li, X., Lin, Z., \& Ma, C. (2011). Proteolysis, protein

Zhang, W., Xiao, S., \& Ahn, D.U. (2013). Protein oxidation: basic principles and implications for meat quality. Critical Reviews in Food Science and Nutrition, 53 (11), 1191-1201. 


\section{FIGURES CAPTIONS}

323 Figure 1. MS/MS spectrum of peptide DKEGNGTVMGAELR from myosin light chain

324 protein (MYL1_BOVIN). B) Spectrum of same peptide showing the oxidised

325 methionine in blue. 
Table 1. Oxidised peptides identified by nESI-LC-MS/MS from actin, titin and troponin I proteins in dry-cured ham.

\begin{tabular}{|c|c|c|c|c|c|c|c|c|}
\hline Protein & & Observed & Calculated & Charge & & & & \\
\hline name $^{a}$ & Species & $(\mathrm{m} / \mathrm{z})^{\mathrm{b}}$ & $(m r)^{c}$ & $(+)$ & $P_{0}{ }^{d}$ & Sequence & $\mathrm{Pf}^{\mathrm{e}}$ & No ox ${ }^{f}$ \\
\hline \multirow[t]{11}{*}{ ACTS } & BOVIN & 293.21 & 876.45 & 3 & $\mathrm{G}$ & IADRMQK & $E$ & 1 \\
\hline & & 530.25 & 1058.47 & 2 & $\mathrm{~F}$ & IGMESAGIHE* & $\mathrm{T}$ & 1 \\
\hline & & 589.31 & 1176.61 & 2 & $\mathrm{~K}$ & EITALAPSTMK* & I & 1 \\
\hline & & 608.31 & 1214.56 & 2 & $\mathrm{P}$ & RHQGVMVGMGQ & $\mathrm{K}$ & 1 \\
\hline & & 636.29 & 1270.55 & 2 & M & VGMGQKDSYVGD* & $E$ & 1 \\
\hline & & 671.32 & 1340.60 & 2 & M & SGGTTMYPGIADR & M & 1 \\
\hline & & 464.24 & 1389.59 & 3 & $\mathrm{D}$ & LYANNVMSGGTTM & $\mathrm{Y}$ & 2 \\
\hline & & 477.82 & 1430.58 & 3 & $\mathrm{Y}$ & ANNVMSGGTTMYPG & 1 & 2 \\
\hline & & 615.32 & 1842.93 & 3 & $\mathrm{~L}$ & TEAPLNPKANREKMTQ & 1 & 1 \\
\hline & & 716.33 & 2145.98 & 3 & $\mathrm{D}$ & LYANNVMSGGTTMYPGIADR & M & 1 \\
\hline & & 856.54 & 2566.35 & 3 & $\mathrm{H}$ & AIMRLDLAGRDLTDYLMKILTE & $\mathrm{R}$ & 1 \\
\hline \multirow[t]{52}{*}{ TITIN } & HUMAN & 561.26 & 1120.51 & 2 & A & RMSPARMSPG & $\mathrm{R}$ & 2 \\
\hline & & 355.07 & 708.35 & 2 & $E$ & VKSQMT & $\mathrm{E}$ & 1 \\
\hline & & 253.18 & 756.28 & 3 & A & SMSAQSM & $S$ & 1 \\
\hline & & 405.26 & 808.37 & 2 & $\mathrm{~K}$ & ASDRLTM & $\mathrm{K}$ & 1 \\
\hline & & 419.31 & 836.41 & 2 & $\mathrm{~K}$ & LTVLNMM & $\mathrm{K}$ & 1 \\
\hline & & 432.24 & 862.47 & 2 & $\mathrm{P}$ & VVTNRKM & $\mathrm{C}$ & 1 \\
\hline & & 439.24 & 876.45 & 2 & $\mathrm{D}$ & HGLYMIK & V & 1 \\
\hline & & 318.52 & 952.41 & 3 & $\mathrm{~S}$ & VEVMETET & A & 1 \\
\hline & & 325.20 & 972.49 & 3 & $\mathrm{G}$ & RPVPAMTW & $\mathrm{F}$ & 1 \\
\hline & & 327.22 & 978.51 & 3 & $\mathrm{R}$ & IDLSVAMKS & L & 1 \\
\hline & & 338.15 & 1011.46 & 3 & $\mathrm{R}$ & TYIPVMSGE & $\mathrm{N}$ & 1 \\
\hline & & 514.28 & 1026.48 & 2 & 1 & DDYLAMKR & $\mathrm{T}$ & 1 \\
\hline & & 531.26 & 1060.43 & 2 & $\mathrm{H}$ & GERYQMDF & L & 1 \\
\hline & & 359.19 & 1074.61 & 3 & $S$ & ASIMVKAINI & A & 1 \\
\hline & & 575.29 & 1148.57 & 2 & I & DLSTMPQKTI & $\mathrm{H}$ & 1 \\
\hline & & 384.16 & 1149.59 & 3 & $\mathrm{R}$ & VDKYKHMLT & I & 1 \\
\hline & & 393.23 & 1176.57 & 3 & $\mathrm{P}$ & IRMSPARMSP & A & 2 \\
\hline & & 598.31 & 1194.54 & 2 & $\mathrm{~N}$ & ADISMGDVATLS & V & 1 \\
\hline & & 399.22 & 1194.58 & 3 & $\mathrm{~T}$ & FQVMAVNSAGR & $S$ & 1 \\
\hline & & 629.44 & 1256.67 & 2 & $\mathrm{~K}$ & EMRLNVLGRPG & $\mathrm{P}$ & 1 \\
\hline & & 650.68 & 1299.49 & 2 & $\mathrm{~T}$ & CQATNDVGKDMC & $S$ & 1 \\
\hline & & 441.30 & 1320.64 & 3 & $\mathrm{R}$ & IAAENSIGMGPFV & $E$ & 1 \\
\hline & & 669.37 & 1336.65 & 2 & $S$ & LEVTNIAKDSMT & V & 1 \\
\hline & & 465.77 & 1394.55 & 3 & $\mathrm{~T}$ & EMKFASMSAQSM & $\mathrm{S}$ & 3 \\
\hline & & 466.24 & 1395.63 & 3 & $S$ & SQSVQMSASKQEA & $S$ & 1 \\
\hline & & 469.25 & 1404.70 & 3 & $S$ & FVQKPDPMDVLT & $\mathrm{G}$ & 1 \\
\hline & & 490.26 & 1467.81 & 3 & $\mathrm{R}$ & LMVSVSGRPPPVIT & W & 1 \\
\hline & & 746.85 & 1491.74 & 2 & $\mathrm{~L}$ & MRKTQASTVATGPE & $\mathrm{V}$ & 1 \\
\hline & & 500.84 & 1499.66 & 3 & $\mathrm{~L}$ & ISQSERCSITMTE & $\mathrm{K}$ & 1 \\
\hline & & 504.28 & 1509.72 & 3 & A & RLMIREAFAEDSG & $\mathrm{R}$ & 1 \\
\hline & & 507.94 & 1520.82 & 3 & $\mathrm{~T}$ & LTVKNASGTKAVSVM & V & 1 \\
\hline & & 510.31 & 1527.73 & 3 & $\mathrm{D}$ & YELLMKSQQEML & $\mathrm{Y}$ & 1 \\
\hline & & 523.34 & 1566.72 & 3 & I & KHGERYQMDFLQ & $\mathrm{D}$ & 1 \\
\hline & & 530.28 & 1587.78 & 3 & $\mathrm{~F}$ & QVMAVNSAGRSAPRE & $S$ & 1 \\
\hline & & 533.27 & 1596.83 & 3 & $\mathrm{~K}$ & VPVTMTRYRSTGLT & $E$ & 1 \\
\hline & & 543.28 & 1626.77 & 3 & $E$ & PPEIDMKNFPSHTV & $\bar{Y}$ & 1 \\
\hline & & 545.30 & 1632.75 & 3 & $\mathrm{~K}$ & GSMLVSWTPPLDNGGS & $\mathrm{P}$ & 1 \\
\hline & & 563.31 & 1686.78 & 3 & $E$ & SYVIEMLKTGTDEW & V & 1 \\
\hline & & 564.29 & 1689.77 & 3 & Q & WTKPVYDGGSMITGY & 1 & 1 \\
\hline & & 567.53 & 1699.71 & 3 & $\mathrm{~S}$ & SFSSSSASSMTEMKFA & $\mathrm{S}$ & 1 \\
\hline & & 871.45 & 1740.90 & 2 & $\mathrm{~K}$ & AMTLGVSYKVTGLIEGS & $\mathrm{D}$ & 1 \\
\hline & & 590.49 & 1768.71 & 3 & $\mathrm{~S}$ & MTEMKFASMSAQSMSS & M & 1 \\
\hline & & 607.59 & 1819.91 & 3 & $\mathrm{P}$ & AVIVEKAGPMTVTVGETC & $\mathrm{T}$ & 1 \\
\hline & & 611.61 & 1831.82 & 3 & $\mathrm{G}$ & LYICKAENMLGESTCAA & $E$ & 1 \\
\hline & & 616.33 & 1845.97 & 3 & $\mathrm{G}$ & FIIERKDAKMHTWR & Q & 1 \\
\hline & & 985.06 & 1967.95 & 2 & $E$ & NLYGISDPLVSDSMKAKD & $\mathrm{R}$ & 1 \\
\hline & & 657.37 & 1968.84 & 3 & $\mathrm{D}$ & GMTLTWYPPEDDGGSQVT & $\mathrm{G}$ & 1 \\
\hline & & 988.49 & 1974.77 & 2 & $\mathrm{~S}$ & ASSMTEMKFASMSAQSMS & $\mathrm{S}$ & 4 \\
\hline & & 718.35 & 2152.09 & 3 & A & NLKMELRDALCAIIYEEI & $\mathrm{D}$ & 1 \\
\hline & & 719.37 & 2155.18 & 3 & $\mathrm{D}$ & KSAAVATVVAAVDMARVREPV & 1 & 1 \\
\hline & & 778.47 & 2332.14 & 3 & $\mathrm{P}$ & IRMSPARMSPARMSPARMSPA & $\mathrm{R}$ & 2 \\
\hline & & 908.31 & 2722.09 & 3 & $\mathrm{~S}$ & SMTEMKFASMSAQSMSSMQESFVE & $\mathrm{M}$ & 2 \\
\hline \multirow[t]{2}{*}{ TNNI2 } & HUMAN & 424.73 & 847.45 & 2 & $\mathrm{~K}$ & SVMLQIAA & $\mathrm{T}$ & 1 \\
\hline & & 327.22 & 978.40 & 3 & 1 & PGSMSEVQE & $\mathrm{L}$ & 1 \\
\hline
\end{tabular}

a Protein name according to Uniprot database. ACTS: Actin, alpha skeletal muscle; TITIN: Titin; TNNI2: Troponin I, fast skeletal muscle. ${ }^{b}$ Molecular ion mass observed in the nESI-LC-MS/MS analysis calculated in Daltons. ${ }^{\circ}$ Calculated relative molecular mass of the matched peptide. ${ }^{\mathrm{d}} \mathrm{Position}$ of the amino acid residue preceding the peptide sequence. ${ }^{\mathrm{e}}$ Position of the amino acid residue following the peptide sequence. ${ }^{\mathrm{f}}$ Number of methionine oxidations in the identified peptide. * Sequences identified with and without methione oxidation. 
Table 2. Oxidised peptides identified by nESI-LC-MS/MS from myosin and nebulin proteins in dry-cured ham.

Table 2. Oxidised peptides identified by nESI-LC-MS/MS from myosin and nebulin proteins in dry-cured ham.

\begin{tabular}{|c|c|c|c|c|c|c|c|c|}
\hline Protein & & Observed & Calculated & Charge & & & & \\
\hline name $^{a}$ & Species & $(\mathrm{m} / \mathrm{z})^{\mathrm{b}}$ & $(\mathrm{mr})^{\mathrm{C}}$ & $(+)$ & $\mathrm{P}_{0}{ }^{d}$ & Sequence & $\mathrm{Pf}^{\mathrm{e}}$ & No ox $x^{\dagger}$ \\
\hline \multirow[t]{4}{*}{ MLRS } & BOVIN & 590.77 & 1179.53 & 2 & $\mathrm{D}$ & AMMKEASGPIN & $\mathrm{F}$ & 2 \\
\hline & & 605.81 & 1209.57 & 2 & M & MKEASGPINFT* & $\mathrm{V}$ & 1 \\
\hline & & 536.25 & 1605.66 & 3 & $\mathrm{R}$ & AAAEGGSSSVFSMFDQ & $\mathrm{T}$ & 1 \\
\hline & & 669.98 & 2006.93 & 3 & $\mathrm{~N}$ & VKNEELDAMMKEASGPIN & $\mathrm{F}$ & 2 \\
\hline \multirow[t]{11}{*}{ MYH1 } & PIG & 413.27 & 824.37 & 2 & $\mathrm{P}$ & TSGKMQGT & $\mathrm{L}$ & 1 \\
\hline & & 511.43 & 1020.57 & 2 & $\mathrm{E}$ & KPMGIFSIL & $\mathrm{E}$ & 1 \\
\hline & & 520.14 & 1038.47 & 2 & $\mathrm{R}$ & WVESMQSML & $\mathrm{D}$ & 1 \\
\hline & & 550.26 & 1098.50 & 2 & $\mathrm{~K}$ & TPGAMEHELV & $\mathrm{L}$ & 1 \\
\hline & & 646.33 & 1290.67 & 2 & $\mathrm{Y}$ & QKMVERRESI & $\mathrm{F}$ & 1 \\
\hline & & 652.32 & 1302.61 & 2 & 1 & IPNETKTPGAME* & $\mathrm{H}$ & 1 \\
\hline & & 668.34 & 1334.63 & 2 & $\mathrm{E}$ & DQVFPMNPPKF* & $\mathrm{D}$ & 1 \\
\hline & & 759.37 & 1516.72 & 2 & $\mathrm{~L}$ & TVKEDQVFPMNPP* & $\mathrm{K}$ & 1 \\
\hline & & 554.29 & 1659.85 & 3 & $\mathrm{~K}$ & IEDEQALAMQLQKK & 1 & 1 \\
\hline & & 636.65 & 1906.91 & 3 & L & TVKEDQVFPMNPPKFD* & $\mathrm{K}$ & 1 \\
\hline & & 488.76 & 1950.87 & 4 & $\mathrm{~N}$ & EVEDLMIDVERSNAACAA & $\mathrm{L}$ & 1 \\
\hline \multirow[t]{7}{*}{ MYH7 } & PIG & 537.28 & 1072.46 & 2 & C & MFPKATDMT & $\mathrm{F}$ & 2 \\
\hline & & 404.26 & 1209.58 & 3 & $\mathrm{~T}$ & KGQNVQQVMY & A & 1 \\
\hline & & 407.86 & 1220.63 & 3 & $\mathrm{R}$ & KELEEKMVSL & $\mathrm{L}$ & 1 \\
\hline & & 656.35 & 1310.63 & 2 & $\mathrm{~V}$ & TKGQNVQQVMY & A & 1 \\
\hline & & 665.42 & 1328.68 & 2 & A & LAKAVYEKMFN & W & 1 \\
\hline & & 522.28 & 1563.71 & 3 & $\mathrm{R}$ & LEEAGGATSVQIEMN & $\mathrm{K}$ & 1 \\
\hline & & 524.27 & 1569.77 & 3 & 1 & QLSHANRMAAEAQK & Q & 1 \\
\hline \multirow[t]{12}{*}{ MYL1 } & BOVIN & 557.25 & 1112.48 & 2 & $\mathrm{~V}$ & FDKEGNGTVM $^{*}$ & $G$ & 1 \\
\hline & & 585.76 & 1169.50 & 2 & V & FDKEGNGTVMG* & A & 1 \\
\hline & & 606.78 & 1211.55 & 2 & $\mathrm{R}$ & VFDKEGNGTVM ${ }^{*}$ & G & 1 \\
\hline & & 635.29 & 1268.57 & 2 & $\mathrm{R}$ & VFDKEGNGTVMG* & A & 1 \\
\hline & & 670.81 & 1339.61 & 2 & $\mathrm{R}$ & VFDKEGNGTVMGA* & $\mathrm{E}$ & 1 \\
\hline & & 498.24 & 1491.70 & 3 & $\mathrm{~F}$ & DKEGNGTVMGAELR* ${ }^{*}$ & $\mathrm{H}$ & 1 \\
\hline & & 543.92 & 1628.76 & 3 & $\mathrm{~F}$ & DKEGNGTVMGAELRH ${ }^{*}$ & $\mathrm{~V}$ & 1 \\
\hline & & 554.29 & 1659.81 & 3 & $\mathrm{~N}$ & AEVKKVLGNPSNEEM & $\mathrm{N}$ & 1 \\
\hline & & 592.29 & 1773.86 & 3 & $\mathrm{~N}$ & AEVKKVLGNPSNEEMN* & A & 1 \\
\hline & & 615.94 & 1844.89 & 3 & $\mathrm{~N}$ & AEVKKVLGNPSNEEMNA & $\mathrm{K}$ & 1 \\
\hline & & 696.54 & 2086.85 & 3 & $\mathrm{E}$ & EVEALMAGQEDSNGCINYE & A & 1 \\
\hline & & 818.40 & 2452.19 & 3 & $\mathrm{~K}$ & VLGNPSNEEMNAKKIEFEQFL & $\mathrm{P}$ & 1 \\
\hline \multirow[t]{21}{*}{ NEBU } & HUMAN & 401.22 & 800.39 & 2 & $\mathrm{~V}$ & KHAMEVA & $\mathrm{K}$ & 1 \\
\hline & & 402.22 & 802.40 & 2 & $\mathrm{~N}$ & ALTMSKH & $\mathrm{L}$ & 1 \\
\hline & & 452.23 & 902.48 & 2 & $\mathrm{~s}$ & PVDMLSIL & L & 1 \\
\hline & & 302.20 & 903.45 & 3 & $\mathrm{~L}$ & SMLGRPDI & $\mathrm{E}$ & 1 \\
\hline & & 911.62 & 910.41 & 1 & $\mathrm{~K}$ & FSSPVDML & G & 1 \\
\hline & & 498.28 & 994.43 & 2 & $\mathrm{R}$ & GKGLTEMED & $\mathrm{T}$ & 1 \\
\hline & & 525.38 & 1048.51 & 2 & $\mathrm{H}$ & TPLDMVSVTA & A & 1 \\
\hline & & 351.22 & 1050.47 & 3 & $\mathrm{Y}$ & TMSPDLPQF & $\mathrm{L}$ & 1 \\
\hline & & 357.20 & 1068.48 & 3 & $\mathrm{~K}$ & SNYSIMLEP & $\mathrm{P}$ & 1 \\
\hline & & 363.19 & 1086.50 & 3 & $\mathrm{Y}$ & HTPADMLSVT & A & 1 \\
\hline & & 551.30 & 1100.54 & 2 & $\mathrm{~K}$ & AHMLKTRND & $\mathrm{Y}$ & 1 \\
\hline & & 408.90 & 1223.50 & 3 & 1 & HTYNMLPDAM & $\mathrm{s}$ & 2 \\
\hline & & 423.24 & 1266.68 & 3 & G & KGKMVGFRSLE & $\mathrm{D}$ & 1 \\
\hline & & 427.27 & 1278.62 & 3 & $\mathrm{~L}$ & LSRVNQITMSD & $\mathrm{K}$ & 1 \\
\hline & & 714.42 & 1426.68 & 2 & $\mathrm{~K}$ & DSQLYKVMKDAN & $\mathrm{N}$ & 1 \\
\hline & & 775.38 & 1548.70 & 2 & $\mathrm{E}$ & KSMSYYETVLDTP & $\mathrm{E}$ & 1 \\
\hline & & 535.62 & 1603.77 & 3 & A & KMQSEREYKKDF & $\mathrm{E}$ & 1 \\
\hline & & 821.49 & 1640.79 & 2 & A & DYADFMKGIGWLPL & G & 1 \\
\hline & & 555.37 & 1662.82 & 3 & D & MLSVTAAKDAQANITN & $\mathrm{T}$ & 1 \\
\hline & & 779.41 & 2335.20 & 3 & $\mathrm{~L}$ & EQVLAKNNALNMNKRLYTEA & W & 1 \\
\hline & & 797.50 & 2389.29 & 3 & $\mathrm{~V}$ & IRKKVDPSKFMTPYIAHSQK & $\mathrm{M}$ & 1 \\
\hline
\end{tabular}

${ }^{2}$ Protein name according to Uniprot database. MLRS: Myosin regulatory light chain 2, skeletal muscle; MYH1: Myosin-1; MYH7: Myosin-7; MYL1: Myosin light chain 1/3, skeletal muscle isoform; NEBU: Nebulin. ${ }^{b}$ Molecular ion mass observed in the nESI-LC-MS/MS analysis calculated in Daltons. ${ }^{\circ}$ Calculated relative molecular mass of the matched peptide. ${ }^{d}$ Position of the amino acid residue preceding the peptide sequence. ${ }^{e}$ Position of the amino acid residue following the peptide sequence. ${ }^{f}$ Number of methionine oxidations in the identified peptide. *Sequences identified with and without methione oxidation. 
Table 3. Characteristics of studied proteins in relation to the Met oxidation identified from the dry-cured ham generated peptides.

\begin{tabular}{|c|c|c|c|c|c|c|c|c|c|}
\hline Protein & Molecular & Protein & Number of & Percentage of & Oxidised & Non-oxidised & Total number & Percentage & Sequence \\
\hline name $^{a}$ & mass (kDa) & lenght (aa) & Methionine & Methionine (\%) & peptides $^{b}$ & peptides $^{c}$ & of peptides $^{d}$ & oxidation (\%) & $\operatorname{coverage}^{\mathrm{e}}(\%)$ \\
\hline TITIN & 3816.03 & 34350 & 398 & 1.15 & 52 & 240 & 292 & 17.81 & 30 \\
\hline NEBU & 772.914 & 6669 & 185 & 2.77 & 21 & 39 & 60 & 35.00 & 23 \\
\hline MYH1 & 223.173 & 1939 & 52 & 2.68 & 11 & 51 & 62 & 17.74 & 30 \\
\hline MYH7 & 223.298 & 1935 & 52 & 2.68 & 7 & 22 & 29 & 24.14 & 32 \\
\hline ACTS & 42.051 & 377 & 17 & 4.5 & 11 & 84 & 95 & 11.58 & 66 \\
\hline TNNI2 & 21.339 & 182 & 10 & 5.49 & 2 & 7 & 9 & 22.22 & 21 \\
\hline MYL1 & 19.505 & 176 & 6 & 3.4 & 12 & 150 & 162 & 7.41 & 80 \\
\hline MLRS & 19.013 & 170 & 17 & 4.11 & 4 & 63 & 67 & 5.97 & 73 \\
\hline
\end{tabular}

${ }^{a}$ Protein name according to Uniprot database. ${ }^{b}$ Number of peptides showing Met oxidation identified in the protein. ${ }^{\mathrm{c}}$ Number of nonoxidised peptides identified in the protein. ${ }^{d}$ Total number of peptides identified. ${ }^{e}$ Percentage of the sequence of origin protein covered by the identified peptides. 


\section{A) DKEGNGTVMGAELR (3+)}

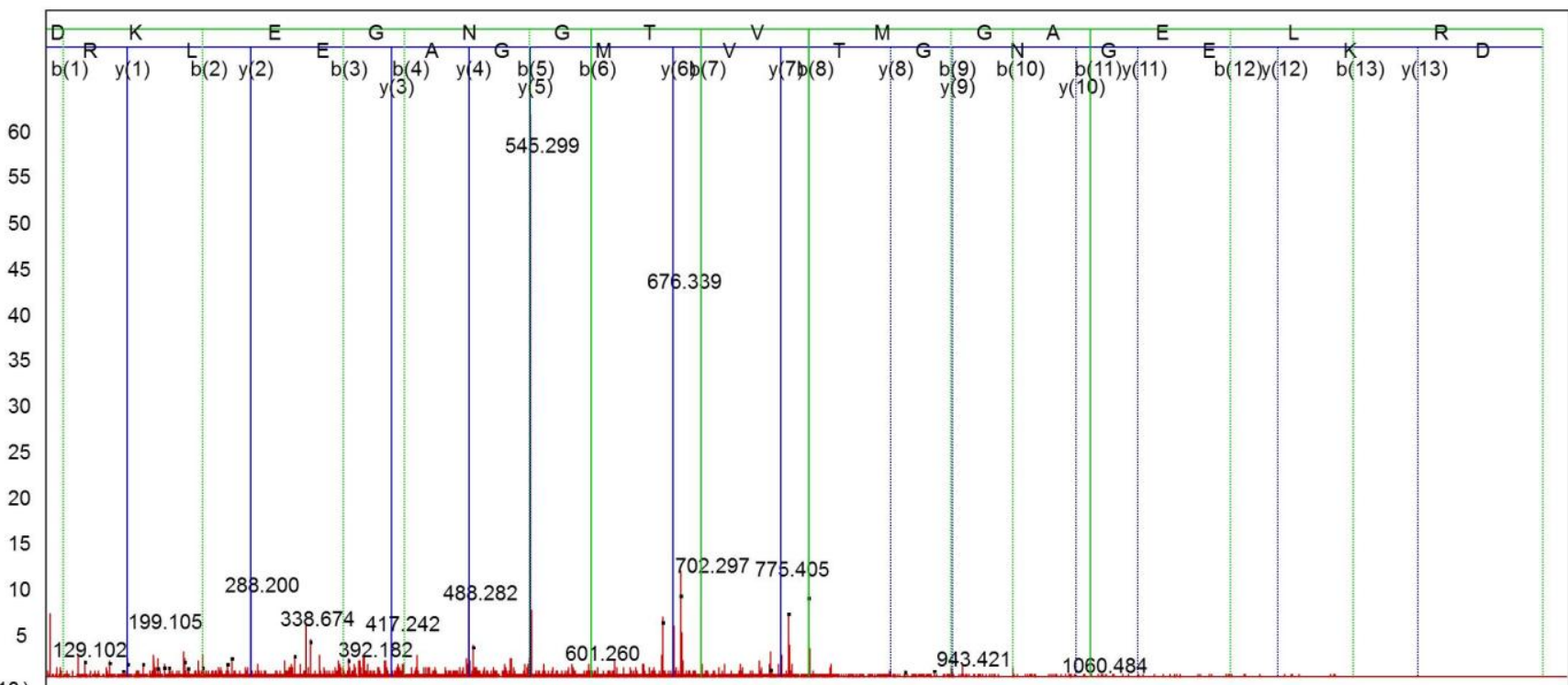

$150200250300350400450500 \quad 550600 \quad 650 \quad 700750800 \quad 850900950100010501100115012001250130013501400 \quad 1450 \mathrm{~m} / 2$

\section{B) DKEGNGTVMGAELR (3+)}

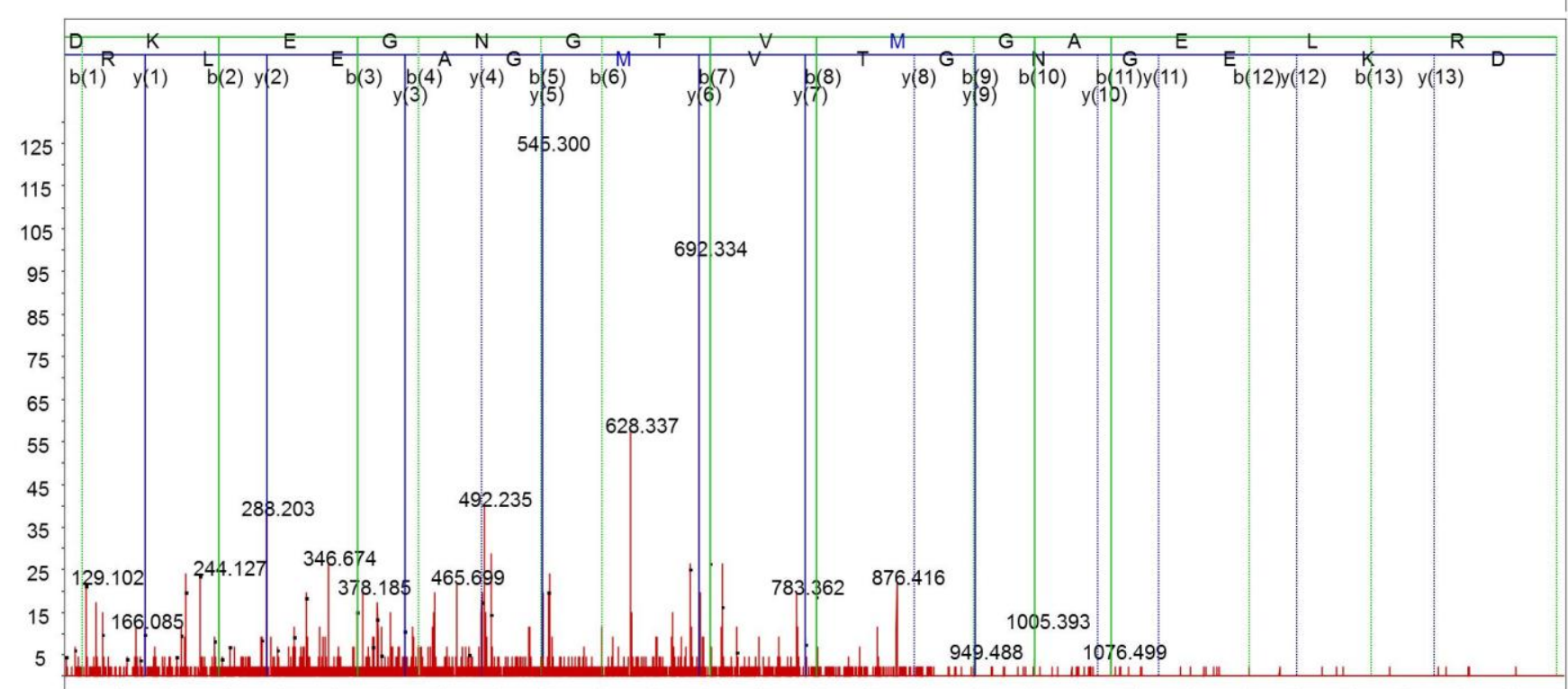

$150200250300350400450500550600650700 \quad 750 \quad 8008509009501000105011001150120012501300135014001450 \mathrm{~m} / 2$ 
Figure 1. A) MS/MS spectrum of peptide DKEGNGTVMGAELR from myosin light chain protein (MYL1_BOVIN). B) Spectrum of same peptide showing the oxidised methionine in blue. 